\title{
Clinical Experience
}

\section{Crohn's Disease in the Elderly Prolonged Delay in Diagnosis}

\author{
Donald M. Foxworthy, MD, and Joanne A. P. Wilson, MD, FACP*
}

Crohn's disease typically afflicts younger patients, with a peak incidence in the third decade of life. ${ }^{1}$ As Crohn's disease infrequently presents in the elderly, the nature and course of the disease among older patients has not been well defined. The presenting symptoms of abdominal pain, fever, and diarrhea so commonly seen with Crohn's disease may suggest other more frequently encountered illnesses in the elderly such as diverticulitis, ischemic colitis, or malignancy. ${ }^{2}$ One easily can see that attributing these complaints to these more common disorders or a failure to consider the diagnosis of Crohn's disease can lead to delay in diagnosis and appropriate therapy in the elderly. In reviewing the experience with Crohn's disease presenting in elderly patients at the University of Michigan, the authors hope to determine clinical characteristics of the disease in these patients and to assess the degree to which specific diagnosis or appropriate therapy was clelayed after presentation with symptoms.

\section{Materials and Methods}

The charts were reviewed of all patients aged 60 years or older discharged with a diagnosis of Crohn's disease from January 1975 to August 1983. Those patients in whom the diagnosis was made after the age of 60 were included in the study and are designated as group 1. The authors evaluated the extent and severity of the disease, the duration of symptoms from time of presentation to the time of diagnosis, the degree to which misdiagnosis caused a delay in treatment, the methods of dingnosis, and the patients' course during follow-up. The diagnosis was accepted as correct when patients had an appropriate clinical presentation and course and had one of the following: radiologic appearance typical of Crohn's disease (three), histologic findings typical of Crohn's disease (four), or a

\footnotetext{
"Assistant Professor, Division of Gastroenterology, Department of Internal Medicine, The University of Michigan Medical Center, Ann Arbor, Michigan.

Address correspondence and reprint requests to $\mathrm{Dr}$. Joanne A. P. Wilson: D-2107 Medical Professional Building, University of Michigan Medical Center, Ann Arbor, MI 48109.
}

typical laparotomy appearance described by a senior surgeon.

Randomly selected charts of young adult patients with Crohn's disease whose ages ranged from 20 to 50 years at the time of diagnosis were examined for identical criteria, and these comprise group 2 . The findings in the older (group 1) and younger (group 2) patients were compared, and, where appropriate, results were analyzed by the Student's $t$ test.

\section{Results}

Ten patients were identified in whom the diagnosis of Crohn's disease was made after age 60 (Table 1), with a range of 60 to 78 years and a mean of $68 \pm 1.6$ years. Five patients were men and five were women. The 20 control patients ranged in age from 20 to 45 years at the time of diagnosis with a mean age of $27 \pm 1.6$ years. Seven were men and 13 were women.

The distribution of disease involvement is presented in Table 1. There was no significant difference between the two groups. Diarrhea and abdominal pain were the most common presenting symptoms and occurred at similar frequency in the two groups. Elderly patients, however, complained of symptoms for a mean of $24 \pm 7$ months (median, 16 months) compared with $10 \pm 3$ months (median, five months) for the younger control subjects, a difference that is statistically significant $(P<.05)$ :

In the elderly patients $60 \%$ were given an incorrect or incomplete diagnosis that caused a delay of more than six months to a diagnosis of inflammatory bowel disease as compared with only $15 \%$ of the younger patients. In these older patients, diverticulitis was the most common misdiagnosis. These cases are included in Table 2. Most of the patients were referrals from outside hospitals and initial evaluation was usually performed at other institutions. As indicated, the other diagnoses that delayed correct diagnosis were gallbladder disease (a coincidental finding of gallstones), sprue (suggested by finding of abnormal glucose tolerance test, but without $x$-ray or histologic evidence), and irritable bowel syndrome with sliding internal 
TABLE 1. Clinical Features of Elderly Patients Versus Younger Patients With Crohn's Disease

\begin{tabular}{lcc}
\hline & Group 1* & Group 2† \\
\hline Patients & 10 & 20 \\
Age & & \\
$\quad$ (mean \pm SEM) & $68 \pm 1.6$ & $27 \pm 1.6$ \\
$\quad$ Range & $60-78$ & $20-45$ \\
Sex (male:female) & $5: 5$ & $7: 13$ \\
Anatomical distribution & & \\
of disease & & \\
$\quad$ lleal & 4 & 4 \\
$\quad$ Ileocolonic & 2 & 15 \\
$\quad$ Colonic & 4 & 1 \\
Presenting symptoms & & 14 \\
$\quad$ Diarrhea & 7 & 17 \\
$\quad$ Abdominal pain & 8 & 5 \\
$\quad$ Weight loss & 5 & 4 \\
$\quad$ Emesis & 4 & 1 \\
$\quad$ Fever & 2 & \\
$\quad$ Perianal disease & 2 & 5 \\
Duration of symptoms & & \\
to diagnosis & & \\
$\quad$ Mean (mo \pm SEM) & $24 \pm 7 \ddagger$ & \\
$\quad$ Median (mo) & 16 & \\
\hline
\end{tabular}

- Diagnosis at greater than age 60.

$\dagger$ Diagnosis at less than age 60.

$¥$ Significance at $P<.05$. hernia. In two of the cases, the diagnosis probably would have been made if small bowel $x$-rays had accompanied the upper gastrointestinal series. Initial misdiagnoses that did not lead to significant delay included ischemic colitis, adenocarcinoma, and peptic ulcer disease because appropriate radiologic and endoscopic procedures were performed.

The diagnostic studies that contributed to confirmation of the correct diagnosis are tabulated in Table 3. Only three elderly patients had radiographic upper gastrointestinal series with small bowel follow through. In two of these three patients, the radiologic findings alone were sufficient to establish the diagnosis of Crohn's disease (all other patients had surgical or endoscopic biopsy confirmation).

Initially, six of the elderly patients were managed medically; however, four underwent immediate surgery. None of these four had a preoperative diagnosis. Seven underwent surgery at some point in their course. The indications for surgery were evenly spread between bowel obstruction (three), intractable pain or bleeding (three), and exploration for diagnosis (four). In retrospect, three of the exploratory procedures possibly could have been avoided if the diagnosis of Crohn's disease had been considered earlier. Among the younger patients, 14 were initially managed medically and six surgically. Of this group only two patients underwent explor-

TABLE 2. Clinical Course of Elderly Patients With Crohn's Disease and Delay in Diagnosis of More Than Six Months

\begin{tabular}{|c|c|c|c|c|c|}
\hline Case & $\begin{array}{c}\text { Age at } \\
\text { Diagnosis }\end{array}$ & Symptoms & $\begin{array}{c}\text { Initial } \\
\text { Diagnostic Studies }\end{array}$ & $\begin{array}{c}\text { Initial } \\
\text { Diagnosis }\end{array}$ & $\begin{array}{c}\text { Final } \\
\text { Diagnosis }\end{array}$ \\
\hline 1 & 73 & $\begin{array}{l}\text { Nausea, emesis, rectal } \\
\text { bleeding }\end{array}$ & $\begin{array}{l}\text { UGI/SBFT: normal } \\
\text { BE: narrowing, lateral } \\
\text { sinus tract }\end{array}$ & Diverticulitis & $\begin{array}{l}\text { Crohn's colitis: sigmoid } \\
\text { obstruction, diagnosis } \\
\text { at laparotomy }\end{array}$ \\
\hline 2 & 73 & $\begin{array}{l}\text { Diarrhea, anal fistula, } \\
\text { anemia }\end{array}$ & $\begin{array}{l}\text { UGI(no SBFT): normal } \\
\text { BE: submucosal sinus } \\
\text { tract, probable } \\
\text { abscess }\end{array}$ & Diverticulitis & $\begin{array}{l}\text { Crohn's colitis: pyoderma } \\
\text { gangrenosum, } \\
\text { diagnosis on sigmoid } \\
\text { biopsy, subsequent } \\
\text { colectomy }\end{array}$ \\
\hline 3 & 65 & $\begin{array}{l}\text { Diarrhea, abdominal } \\
\text { pain, rectal bleeding, } \\
\text { acute abdomen }\end{array}$ & $\begin{array}{l}\text { BE(later): sigmoid } \\
\text { narrowing } \\
\text { Surgery: diverting } \\
\text { colostomy }\end{array}$ & $\begin{array}{l}\text { Diverticulitis } \\
\text { with perforation }\end{array}$ & $\begin{array}{l}\text { Crohn's colitis: diagnosis } \\
\text { at time of sigmoid } \\
\text { resection }\end{array}$ \\
\hline 4 & 66 & $\begin{array}{l}\text { Abdominal pain, } \\
\text { diarrhea }\end{array}$ & $\begin{array}{l}\text { UGI(no SBFT): normal } \\
\text { BE(x2): diverticuli } \\
\text { Cholelithiasis }\end{array}$ & Cholelithiasis & $\begin{array}{l}\text { Crohn's ileocolitis: } \\
\text { diagnosis at time of } \\
\text { cholecystectomy }\end{array}$ \\
\hline 5 & 70 & $\begin{array}{l}\text { Diarrhea, nausea, } \\
\text { bloating, no weight } \\
\text { loss, no anemia }\end{array}$ & $\begin{array}{l}\text { UGI(no SBFT): normal } \\
\text { BE: normal } \\
\text { Sigmoidoscopy: } \\
\text { hemorrhoids }\end{array}$ & $\begin{array}{l}\text { Irritable bowel } \\
\text { syndrome }\end{array}$ & $\begin{array}{l}\text { Crohn's ileitis: partial } \\
\text { bowel obstruction, } \\
\text { diagnosis at laparotomy } \\
\text { and resection }\end{array}$ \\
\hline 6 & 67 & $\begin{array}{l}\text { Diarrhea, abdominal } \\
\text { pain }\end{array}$ & UGI(no SBFT): normal & Sprue & $\begin{array}{l}\text { Crohn's ileitis: } \\
\text { subsequent abnormal } \\
\text { UGI/SBFT }\end{array}$ \\
\hline
\end{tabular}

UGI = upper gastrointestinal series; SBFT = small bowel follow through; $B E=$ barium enema. 
TABLE 3. Procedures Contributing to Diagnosis of Crohn's Disease

\begin{tabular}{lcc}
\hline \multicolumn{1}{c}{ Patients } & $\begin{array}{c}\text { Group 1* } \\
(N=10)\end{array}$ & $\begin{array}{c}\text { Group 2t } \\
(N=20)\end{array}$ \\
\hline $\begin{array}{l}\text { Upper gastrointestinal } \\
\text { series with small } \\
\text { bowel study }\end{array}$ & 3 & \\
Barium enema & 4 & 12 \\
Colonoscopy & 3 & 5 \\
Sigmoidoscopy & 3 & 2 \\
Surgery & 5 & 2 \\
Angiography & 1 & 5 \\
\hline "Diagnosis at greater than age 60. & \\
† Diagnosis at less than age 60.
\end{tabular}

atory laparotomy for diagnosis. Fifteen of the patients eventually required an operation. During the follow-up period (mean, 3.6 years for the older group), no patients died of the disease or from complications of surgery.

\section{Discussion}

During the past two decades, various conclusions have been drawn about the natural history of Crohn's disease affecting older patients. Some believe that the data suggest that the disease more often manifests as a granulomatous colitis, which is relatively indolent and rarely requires surgical intervention. ${ }^{5-7}$ Others claim that elderly patients frequently have ileal disease, often require multiple operations, and have high mortality and morbidity. ${ }^{8} \mathrm{~A}$ third contingent has found the disease to be similar in young and old patients. ${ }^{9}$ Each of these studies was too small to permit a concensus. Recently, Shapiro et al. ${ }^{10}$ identified 33 patients at Beth Israel Hospital who presented with Crohn's disease after age 60 years. The distribution of disease involvement corresponded closely with the authors' findings. Both studies suggest that isolated ileal disease is more frequent and ileocolic involvement less common than in the general population of Crohn's patients as typified by the study by Farmer et al." of 615 patients. Otherwise, the presenting symptoms, initial management, eventual need for surgery and re-operation, and ultimate outcome appear to be similar for older and younger groups of hospitalized patients.

Approximately 3 to $5 \%$ of patients with Crohn's disease are diagnosed after age 60 , and the incidence of Crohn's disease in the elderly has been calculated at two cases per 10,000 people over age 60 per year. ${ }^{12}$ In these few individuals, the differential diagnosis for abdominal symptomatology is much broader, and these cases would seem particularly at risk of misdiagnosis. Other common ill- nesses, such as diverticulitis, may coexist with Crohn's disease, and radiologic findings may be less conclusive than in younger patients. ${ }^{13}$ Meyers et al. ${ }^{13}$ found that half of elderly patients with Crohn's colitis had granulomatous inflammation of diverticuli on pathologic examination. This study suggests that Crohn's disease may actually increase the incidence of diverticuli in these patients and that long fistulous sinus tracts demonstrated on barium enema should raise the suspicion of Crohn's involvement of diverticuli. Crohn's disease may mimic ischemic bowel disease on barium studies, ${ }^{12}$ and endoscopy or surgery may be required to differentiate the two disorders.

That elderly patients with Crohn's disease had a significant delay in diagnosis compared with younger controls had been predicted by earlier, anecdotal reports. ${ }^{14}$ Crohn's disease in general may be difficult to diagnose. Admans et al. ${ }^{15}$ concluded that only $20 \%$ of all patients are correctly diagnosed after the initial investigation of symptoms, and approximately $60 \%$ after the first year. The National Cooperative Study of Crohn's Disease ${ }^{16}$ suggested a marked delay for all patients from the onset of symptoms to a correct diagnosis. The present study found that this interval to diagnosis was significantly longer in the elderly when compared with younger patients. As well, the elderly patients had fewer radiographic and endoscopic studies that would lead to correct diagnosis. This presumably led to the increased use of exploratory laparotomy for diagnosis in these patients.

Although Crohn's disease is unusual in elderly patients, the diagnosis should be considered in cases presenting with diarrhea, abdominal pain, and fever, or when older patients with common bowel diseases have prolonged, complicated, or atypical courses. Small bowel radiography and colonoscopy with biopsy should be performed earlier in these cases, and reexamination of previous pathology specimens, when available, is indicated to avoid unnecessary or inappropriate medical therapy.

\section{References}

1. Truelove SC, Pena AS: Course and prognosis of Crohn's disease. Gut 17:192, 1976

2. Carr N, Schofield PF: Inflammatory bowel disease in the oider patient. Br J Surg 69:223, 1982

3. Marshak $\mathrm{RH}$, Lindner AE: Radiologic diagnosis of chronic ulcerative colitis and Crohn's disease, in Kirsner JB. Shorter RG (eds): Inflammatory Bowel Disease. Philadelphia, Lea \& Febiger, 1980, pp 341-412

4. Whitehead R: Pathology of Crohn's disease, in Kirsner JB, Shorter RG (eds): Inflammatory Bowel Disease. Philadelphia, Lea \& Febiger, 1980, pp 296-310

5. Lockhart-Mummery HE: Crohn's disease of the large bowel. $\mathrm{Br}$ J Surg 59:823, 1972

6. Editorial: Crohn's disease in the elderly: a diagnostic problem. Br Med J 3:188, 1973 
7. Kyle J: An epidemiological study of Crohn's disease in Northeast Scotland. Gastroenterology 61:826, 1972

8. Rusch V, Simoniwitz D: Crohn's disease in the older patient. Surg Gynecol Obstet 150:184, 1980

9. Fromm J, Wilson FA, Rodgers JB, et al: Granulomatous bowel (Crohn's) disease. Arch Intern Med 128:739, 1971

10. Shapiro P, Peppercorn MA, Antonioli DA, et al: Crohn's disease in the elderly. Am J Gastroenterol 76:132, 1981

11. Farmer RG, Hawk WA, Turnbull RB: Clinical patterns in Crohn's disease: a statistical study of 615 cases. Gastroenterology $68: 627,1975$
12. Brahme $F$, Lindstrom $C$. Wenckert $A$ : Crohn's disease in a defined population. Gastroenterology 69:342, 1975

13. Meyers MA, Alonso DR, Morson BC, et al: Pathogenesis of diverticulitis complicating granulomatous colitis. Gastroenterology 74:24, 1978

14. Hoffman W, Rosenberg M: Granulomatous colitis in the elderly, Am J Gastroenterol 58:508, 1972

15. Admans $H$. Whorwell $P J$, Wright R: Diagnosis of Crohn's disease. Dig Dis Sci 25:911, 1980

16. Mekhjian HS, Switz DM, Melnyk CS, et al: Clinical features and natural history of Crohn's disease. Gastroenterology 77:898, 1979 